\title{
ABOUT POSSIBILITY TO CLASSIFY COAL LAYERS HAZARDOUS CHARACTERISTICS BY GENETIC AND PROCESS PARAMETERS OF COALS
}

\author{
${ }^{1}$ Professor, Mykola Antoshchenko, \\ ${ }^{1}$ Associate Professor, Vadym Tarasov, \\ ${ }^{2}$ Associate Professor, Mihail Filatiev, \\ ${ }^{2}$ Assistant Professor, Elvira Filatieva, \\ ${ }^{3}$ Field Production Engineer, Oleg Levadnyi
}

Ukraine, Severodonetsk, Volodymyr Dahl East Ukrainian National University;

${ }^{I}$ Department of Chemistry and Industrial Safety Measures

${ }^{2}$ Department of Chemical Engineering and Ecology

${ }^{3}$ Kazakhstan, Production Field Tengiz, Ariadna LLP

DOI: https://doi.org/10.31435/rsglobal_sr/31012020/6870

\section{ARTICLE INFO}

Received 18 November 2019

Accepted 17 January 2020

Published 31 January 2020

\section{KEYWORDS}

metamorphism, spontaneous fire, geological and genetic factors, elemental constituents.

\begin{abstract}
The analysis of Ukrainian legal environment has been performed for solid fossil fuels production, which has shown existing of contradictories between parameters describing the accuracy of forecast to manifest the coal layers hazardous characteristics during independent of mining and does not exclude any possibility for emergency situation to occur, independent of the preventive measures full implementation. The base to determine the coal layers hazardous characteristics are: average reflectance of vitrinite, presence of some components in organic matter $\left(\mathrm{C}^{0}, \mathrm{O}^{0}, \mathrm{H}^{0}, \mathrm{~N}^{0}\right)$, alteration of moisture and mineral impurities content. For these classificatory parameters, their quantitative assessment is available in the whole multiplicity of coals metamorphic transformation. The specific electrical resistivity logarithm and other proxy parameters may serve as additional classificatory parameters to reveal any hazardous characteristics of anthracites after grounding their using in some ranges of metamorphism series. It has been established that the existing wide range of vitrinite reflectance alteration for anthracites specifies significant alterations in the fossil fuel structure and properties. In their process of metamorphism, these peculiarities of anthracite alterations have almost not been classificatory established by their genetic and process parameters.
\end{abstract}

Citation: Mykola Antoshchenko, Vadym Tarasov, Mihail Filatiev, Elvira Filatieva, Oleg Levadnyi. (2020) About Possibility to Classify Coal Layers Hazardous Characteristics by Genetic and Process Parameters of Coals. Science Review. 1(28). doi: 10.31435/rsglobal_sr/31012020/6870

Copyright: (C) 2020 Mykola Antoshchenko, Vadym Tarasov, Mihail Filatiev, Elvira Filatieva, Oleg Levadnyi. This is an open-access article distributed under the terms of the Creative Commons Attribution License (CC BY). The use, distribution or reproduction in other forums is permitted, provided the original author(s) or licensor are credited and that the original publication in this journal is cited, in accordance with accepted academic practice. No use, distribution or reproduction is permitted which does not comply with these terms.

Introduction. In many cases during mining activities, working the coal layers out becomes complicated due to the hazardous characteristics of coals. The hazardous characteristics include gas bearing capacity of coals, gas-dynamic phenomena, coal ignitability, coal dust explosibility, and increased capability of coals to dust generation. Such properties of coals, when certain conditions of working the coal layers out occur, may lead to underground accidents with severe sequences. During mining activities, manifestation of hazardous characteristics of coals is conditioned by the impact of a variety genetic, mining-and-geological, and mining-engineering factors. They represent, on the one 
hand - components and quantities of coals, on the other hand - mining conditions of coal layers working out. Genetic and technological characteristics of the fossil coals play one of the key roles in the coal layers hazardous characteristics manifestation. They have been formed in result of longlasting geological organic matter transformations under impact of pressure and temperature during the metamorphic processes. In general, the metamorphism means different endogenous processes, which are connected with changes in structure, properties, organic and mineral composition.

To characterize metamorphic processes, the Ukrainian legal environment, which regulates the safe conditions of coal layers working out [1-3], uses only several classificatory parameters separately. The main of them is the volatile yield during thermal decomposition of coals in an anaerobic environment $\left(V^{d a f}\right)$. As per its physical meaning, $V^{\text {daf }}$ parameter describes the elemental constituents of coals in some extent. In addition, to describe the anthracites, the volatile volume yield $\left(V_{v}^{d a f}\right)$ or specific electrical resistivity $\log$ arithm $(\lg \rho)$ is used.

Upon attribution of coal layers to those threatened by abrupt coal and gas outbursts, would be integrated index of metamorphism intensity $M[1]$ is used. At $V^{d a f}=9 \div 29$

$$
M=V^{\text {daf }}-0,16 \cdot y, \text { c.u, }
$$

where $y$ is a thickness of their plastic layer, $\mathrm{mm}$.

At $V^{d a f}>29 \%$

$$
M=\frac{4 \cdot V^{\text {daf }}-91}{y+2,9}+24, \text { c.u. }
$$

Apriori, the index of metamorphism intensity $M$ (equations 1,2) cannot give integrated characteristics of the whole variety of elemental constituents, structure, and properties of coals in the whole multiplicity of their metamorphic transformation. It may be explained by the following reasons:

- the volatile yield is the total percentage of gases escaped from the coal charge. The gases of thermal decomposition of coals in an anaerobic environment are: hydrogen $\left(\mathrm{H}_{2}\right)$, methane $\left(\mathrm{CH}_{4}\right)$, carbon monoxide $(\mathrm{CO})$, and carbon dioxide $\left(\mathrm{CO}_{2}\right)$. The relation between these gases is not constant depending on $V^{\text {daf }}[4]$. This fact is ignored by $V^{d a f}$;

- by nature, $V^{d a f}$ describes its correlation relationships with the organic matter [4,5] principal constituents $\left(C^{0}, O^{0}, H^{0}, N^{0}\right)$;

- as classificatory parameter, $V^{\text {daf }}$ does not reflect the whole variety of organic matter elemental constituents in the whole multiplicity of coals metamorphic transformation. It may not be applied to describe the composition and properties of anthracites. Due to this, during assessment of hazardous characteristics of coals, instead of $V^{d a f}$, additional parameters $V_{v}^{d a f}$ or $\lg \rho$. [1,2] shall be used, which are not applied to determine $M$ as per equations 1, 2;

- classificatory parameters $V^{d a f}$ and $y$ reflect different aspects of coals transformation during metamorphic processes. Empiric equations $(1,2)$ artificially combine different dimensionalities (\% and $\mathrm{mm}$ ) of these parameters. Due to this reason, $M$ is evaluated in conditional units (c.u.). Until now, no close correlation relationships between parameter $M$ and alteration of coals elemental constituents, and their physical and mechanical, and chemical properties.

The above facts evidence that upon forecasting the hazardous characteristics of fossil coals in regulations [1-3], with no scientific justification, the parameters $\left(V^{d a f}, M\right)$ and their metamorphism intensity are equalized. This fact may essentially influence the forecast of coal layers hazardous characteristics manifestation during the mining activities and does not exclude casualty-producing capacity independent of the preventive measures full implementation.

Given the circumstances in the Ukrainian legal environment concerning the coals hazardous characteristics manifestation, the metamorphism intensity reliable determination is an issue important today from the point of view of mining safe conditions.

Purpose of the study: to find the additional genetic and process classificatory parameters of coal rank and capability of their use to forecast the coal layers hazardous characteristics; give suggestions and basic trends in development of coals hazardous characteristics classification by genetic and process criteria.

Methods of research. It is known more than twenty classificatory parameters $[4 \div 8]$, which describe alteration of composition and properties of coals under impact of metamorphic processes. During development of classifications by genetic and process parameters for industrial usage of coals, it was applied six-seven [4,9]; and now it is applied ten [10] classificatory parameters. Accumulated experience of using the industrial classifications and available experimental data [4-10] make it 
possible to consider development of the coal layers hazardous characteristics classification by genetic and process parameters of the fossil coals involving the required number of parameters. It allows improving the requirements of regulations [1-3] in respect of the coal layers hazardous characteristics forecast. For industrial coal classifications $[4,9,10]$, different number of classificatory parameters is adopted. Each classification has different group of main parameters.

When developing the Donets Basin Geological and Coal Chemistry Map [4], such a group was compiled with the following parameters: content of oxygen $\left(O^{0}\right)$ and carbon $\left(C^{0}\right)$ in the organic matter; calorific value for wet ash free state $\left(Q_{S}{ }^{d a f}\right)$; plastic layer thickness $(y)$; semi-coking resin yield for dry ash free state $\left(T_{S K}^{d a f}\right)$; and material factor $\left(F_{m}\right)$.

A little different approach to selection of classificatory parameters was applied for fossil coals quality evaluation in the USSR [9]. The group of parameters included: the coal ranks (D, G, GZh, Zh, KZh, K, K2, OS, SS, T); metamorphism stage (six stages from I to VI); water capacity for ash free state $\left(W^{d a f}\right)$; volatile yield for dry ash free state $\left(V^{d a f}\right)$; plastic layer thickness $(y)$; gross calorific value $\left(Q_{S}{ }^{d a f}\right.$ and $\left.Q_{s}\right)$. The following classification of coals is used in Ukraine (GOST 19242-73): D (Д) Long-Flame; G $(Г)$ - Gas; GZh (ГЖ) - Gas Fat, Zh (Ж) - Fat; KZh (КЖ) - Coking Fat, K (К) Coking; OS (OC) - Lean Coking; SS (CС) - Low-coking; Т (Т) - Green; В (Б) - Brown; DG (ДГ) Long-flame Gas; GZhO (ГЖО) - Gas Fat Lean; KO (КО) - Coking Lean; KSN (КCH) - Coking Lowcoking Low-metamorphosed; KS (KC) - Coking Low-coking; TS (TC) - Green Coking; A (A) Anthracite; GV (ГВ) - Gas Vitrinite; AF (AФ) - Anthracite Fusinite; AV (AB) - Anthracite Vitrinite.

When developing the GOST on coals classification as per their genetic and process parameters [10], ten main parameters were used: average reflectance of vitrinite $\left(\mathrm{R}_{\mathrm{o}}\right)$; gross calorific value for wet ash free state $\left(Q_{S}{ }^{\text {daf }}\right)$; volatile yield for dry ash free state $\left(V^{\text {daf }}\right)$; maximum water capacity for ash free state $\left(W_{\max }{ }^{d a f}\right)$; total fusainized components for clean coal $\left(\sum O K\right)$; semi-coking resin yield for dry ash free state $\left(T_{S K}^{d a f}\right)$, plastic layer thickness $(y)$, free swelling index $(S I)$; volatile volume yield for dry ash free state $\left(V_{v}^{d a f}\right)$; and vitrinite reflectance anisotropic index $\left(A_{R}\right)$. With regards to the trend of application of industrial classifications $[4,9,10]$, they consider only two figures to be the common key indices - gross calorific value for wet ash free state $\left(Q_{s}^{d a}\right)$ and plastic layer thickness $(y)$. It should be expected that based on conditions of their determination, these parameters cannot be key ones to describe the metamorphic processes. They do not directly impact manifestation of the coal hazardous characteristics. With additional grounding, they may be used for the purposes under consideration in some ranges of metamorphism series.

Carbon content $\left(C^{0}\right)$ in the organic matter and average reflectance of vitrinite $\left(R_{o}\right)$ may serve as a base to determine the coal hazardous characteristics in their whole metamorphism series. Both these parameters have numerical values to evaluate the coals transformation degree in all the stages of metamorphism manifestation. The carbon elemental content may indicate presence of the total of other organic matter components, and $R_{o}$ value - probable alteration of coal characteristics in different stages of their transformation.

In classification as per genetic and process parameters [10], the larger number of parameters was used in comparison with other classifications. Due to this, the research methodology provides its structural principle analysis and finding possibility to apply some parameters to develop the coal layers hazardous characteristics classification.

Research results. By ten classificatory parameters, the coals are divided [10] by types, ranks, grades, sub-grades, orders, sub-orders. Division of the fossil coals by types shall be performed as per different combination of three parameters: $R_{o}, Q_{S}{ }^{d a f}$, and $V^{d a f}$ :

brown coal (lignite) $-R_{0} .<0.59 \%, Q_{S}^{\text {daf }}<24 \mathrm{MJ} / \mathrm{kg}$;

bituminous coal $-0.40<R_{o} .>2.59 \%, Q_{S}{ }^{d a f}=24 \mathrm{MJ} / \mathrm{kg}$ and more, $V^{\text {daf }}>8 \%$;

anthracites $-R_{o}=2.20 \%$ and more, $V^{d a f}<8 \%$.

The least alteration of main parameter $\left(\mathrm{R}_{\mathrm{o}}\right)$ has been established for brown coals - less than $0.60 \%$; for bituminous coals, it amounts to $0.40 \div 2.59 \%$, and for anthracites - from $2.20 \%$ and more than $5.00 \%$. No distinct boundaries between fuel types have been designated by the main parameter $\left(R_{o}\right)$. Between brown coals and bituminous coals, the common variation interval of $R_{o}$ amounts to $0.20 \%$; and between the bituminous coals and anthracites, it is almost twice greater $-0.39 \%$.

As per main and proxy parameters, 17 coal ranks have been specified (B, D, DG, G, GZhO, GZh, Zh, KZh, K, KO, KSN, KS, OS, TS, SS, T, A). In turn, the coal ranks have been divided by 27 grades and 44 sub-grades.

Division of the fossil coals by classes, categories, orders, and sub-orders shall be performed using the classification parameters shown in Table 1. 
Table 1. Classificatory parameters to establish classes, categories, orders, and sub-orders [10].

\begin{tabular}{|l|l|l|l|l|}
\hline \multirow{2}{*}{ Types of coals } & \multicolumn{4}{|l|}{ Classificatory parameters } \\
\cline { 2 - 5 } & Classes & Categories & Orders & Sub-orders \\
\hline Brown coal & $R_{0}$. & $\sum O K$ & $W_{\max }$ daf & $T_{S K}$ daf \\
\hline Bituminous coal & $R_{0}$. & $\sum O K$ & $V^{\text {daf }}$ & $y, S I$ \\
\hline Anthracite & $R_{0}$. & $\sum O K$ & $V_{v}^{\text {daf }}$ & $A_{R}$ \\
\hline
\end{tabular}

For different types of coals, value of $\sum O K$ parameter is hardly different, when establishing categories. In almost all cases, $\sum O K$ value amounts to 39 or more than $40 \%$. Exclusions take place for coal ranks $2 \mathrm{G}, 1 \mathrm{GZh}, 2 \mathrm{GZh}$, and rank $\mathrm{KZh}$; for them, $\sum O K$ may take a value less than $10 \%$, and from 10 to 69 and more percent. Taking into account such an uncertainty of $\sum O K$ alteration for the above coals; it is impossible to determine any hazardous characteristics of coals and coal layers using this value. Division of brown coals by orders using the maximum water capacity for ash free state $\left(W_{\max }{ }^{d a}\right)$ is made in the wide range of parameter alteration. For $1 \mathrm{~B}$ grade, $W_{\max }$ daf value is adopted more than $60 \%$; for $2 \mathrm{~B}$ grade $-30 \div 50 \%$; for $3 \mathrm{~B}$ grade- up to $30 \%$. $W_{\max }{ }^{\text {daf }}$ parameter has an important significance, when defining the hazardous characteristics of bituminous coals and anthracites. When developing the classification on determination of hazardous characteristics, both, moisture and mineral impurities content shall be considered in the whole range of coal metamorphism series.

$V^{d a f}$ parameter adequately describes orders of bituminous coals, but there are some uncertainties in determination of boundaries between grades and sub-grades. For example, for coals of $1 \mathrm{G}$ grade, $1 \mathrm{GV}$ subgrade, no upper parameter value has been determined. For this case, $V^{d a f}=38 \%$ and more. Such an approach to determine $V^{\text {daf }}$ alteration boundaries is kept for many ranks, grades, sub-grades, and classes. During development of coals classification by manifestation of their hazardous characteristics, it is desirable for this disadvantage to be eliminated. Advantage of $V^{d a f}$ parameter for its application for any purposes consists in its sufficient previous study in part of correlation relationship with other parameters. High matching correlation coefficients $(r) V^{d a f} \mathrm{c} \mathrm{R}_{0} .(r=-0.883)$ with organic matter constituent elements $C^{\text {laf }}(r=-0.902), H^{\text {daf }}(r=0.798), O^{\text {daf }}(r=0.839)$, etc. [11] have been established. It gives possibility for more detailed study of impact of other factors to the bituminous coals metamorphism intensity.

Volatile volume yield for dry ash free state $\left(V_{v}^{d a f}\right)$ describes the ranks, grades and sub-grades of anthracites very uncertainly. For anthracites of sub-grade $1 \mathrm{AV}, V_{v}{ }^{d a f}$ amounts more than $200 \mathrm{~cm}^{3} / \mathrm{g}$; for $1 \mathrm{AF}, 2 \mathrm{AV}, 2 \mathrm{AF}-100 \div 150 \mathrm{~cm}^{3} / \mathrm{g}$ and more. Statistical processing [5] of observed data [4, 12, 13] has shown that the alteration range $\left(V_{v}{ }^{d a f}\right)$ amounts $50 \div 300 \mathrm{~cm}^{3} / \mathrm{g}$. This suggests the necessity to use additional parameters for the anthracites hazardous characteristics. For example, specific electrical resistivity logarithm $(\lg \rho)$ has correlation relationship $(r=0.84-0.91)$ with the natural gas content of layers [5, 14]; and at $\lg \rho<2.5$, no gas content of anthracites is present. In general, it is necessary to study any additional classificatory parameters to determine the anthracite hazardous characteristics in sufficiently broad range $\left(2.20 \div 5.00 \%\right.$ и выше) of $R_{o}$. alteration.

Semi-coking resin yield for dry ash free state $\left(T_{S K}{ }^{d a f}\right)$ does not give any certain recommendations to divide the brown coals by sub-orders. Additional study is required for its application Its applicability for hazardous characteristics determination requires to be studied additionally.

The plastic layer thickness $(y)$ is used for division of the bituminous coal by sub-orders. In the metamorphism series, depending on $V^{d a f}$, its alteration is ambiguous $[4,5]$. When decreasing $V^{d a f}$ approximately down to $30 \%, y$ value increases from zero up to $14 \div 37 \mathrm{~mm}$. During further decreasing of $V^{\text {daf }}$ down to $17 \div 11 \%, y$ parameter decreases down to zero. Taking into account the character of $y$ alteration, this parameter may be used to determine the coal layers hazardous characteristics.

Free swelling index $(S I)$ has numerical definition for limited number of coal sub-orders at y $<$ $6 \mathrm{~mm}$. They include coals of D, TS, SS, and T ranks. SI parameter establishes definite characteristics of bituminous coals at $R_{o}=0.40 \div 0.79 \%$ for D rank; and TS, SS, T at $R_{o}=0.70 \div 2.59 \%$. In the metamorphism series, there are DG, G, GZhO, GZh, KZh, K, KO, KSN, KS, OS between these ranks. For them, no numerical definition of SI parameter exists. This suggests the need of more detailed study of potential impact of $S I$ to the hazardous characteristics of bituminous coals. It is confirmed by the conclusions [15] that the coals classification by ranks [10] does not ensure their division by consumer properties; and the main - the ranks do not reflect the coking properties of coals.

The vitrinite reflectance anisotropic index $\left(A_{R}\right)$ gives no possibility to divide the anthracites with indication of lower and upper limit upon alteration of the main parameter $\left(R_{o}\right)$ within $2.20 \div$ $4.50 \%$ and more. 
Based on the wide limits of $R_{o}$ alteration, for anthracites, it means that they have significant alterations in their structure and properties. These specialties of anthracites alterations during their metamorphism are hardly established by the classification on genetic and process parameters [10].

Conclusions. The studies performed allowed to make conclusions as for possibility to create the classification of coal layer hazardous characteristics by genetic and process coal parameters:

- the metamorphic processes of coals transformations during determination of the coal layers hazardous characteristics shall be understood as different endogenous processes related to alterations in structure, properties, organic and mineral composition of the mineral deposit. Such alterations in the fossil coals may not be reliably determined using one-two classificatory parameters, as it is customary in the Ukrainian legal environment on safety mining;

- legal environment on determination of the bituminous coal layers hazardous characteristics actually uses only one classificatory parameter - their volatile mass yield during the thermal decomposition of coals in an anaerobic environment. Using this parameter, it is impossible to determine the alteration of hazardous characteristics for anthracites. To characterize the anthracites in another range of the metamorphism series, the regulations use their volatile volume yield or specific electrical resistivity logarithm;

- volatile mass yield as classificatory parameter does not take into account the relation between gases $\left(\mathrm{H}_{2}, \mathrm{CH}_{4}, \mathrm{CO}, \mathrm{CO}_{2}\right)$ escaping during the thermal decomposition of coals. This parameter is only partially correlated with organic matter principal constituents $\left(C^{0}, O^{0}, H^{0}, N^{0}\right)$;

- base to determine the coal layers hazardous characteristics are: average reflectance of vitrinite, presence of some components in organic matter $\left(C^{0}, O^{0}, H^{0}, N^{0}\right)$, alteration of moisture and mineral impurities content. For these classificatory parameters, their quantitative assessment is available in the whole multiplicity of coals metamorphic transformation;

- specific electrical resistivity logarithm and other proxy parameters may serve as additional classificatory parameters to reveal any hazardous characteristics of anthracites after grounding their using in some ranges of metamorphism series.

\section{REFERENCES}

1. SOU 10.1.00174088.011 - 2005. Pravila vedeniya gornyh rabot na plastah, sklonnyh k gazodinamicheskim yavleniyam. Izdanie oficialnoe. Minugleprom Ukrainy. K.: - 2005 - 221s.

2. Rukovodstvo po proektirovaniyu ventilyacii ugolnyh shaht. - K.: - Osnova. - 1994. - 311s.

3. Rukovodstvo po borbe s pylyu v ugolnyh shahtah. - M.: Nedra. $-1979 .-319$ s.

4. Geologo-uglehimicheskaya karta Doneckogo bassejna. - DonUGI - Vyp.VIII - M.: Ugletehizdat. - 1954. - 430s.

5. Antoshenko N.I., Shepelevich V.D. Metan v ugolnyh plastah ot obrazovaniya lo vydeleniya. - Alchevsk: DonGTU. - 2006. - 267s.

6. Gapeev A.A. Tvyordye goryuchie iskopaemye (kaustobiolity). - M.: Gosudarstvennoe izdatelstvo geologicheskoj literatury. - 1949. - 335s.

7. Saranchuk V.I., Ajruni A.T., Kovalyov K.E. Nadmolekulyarnaya organizaciya, struktura i svojstva uglej. K.: Naukova dumka. - 1988. - 192s.

8. Tajc E.M., Andreeva I.A. Metody analiza i ispytaniya uglej. - M.: Nedra. - 1983. - 301s.

9. Mironov K.V. Spravochnik geologa-ugolshika. - M.: Nedra. - 1982. - 311s.

10. GOST 25543-2013. Mezhgosudarstvennyj standart. Ugli burye, kamennye i antracity. Klassifikaciya po geneticheskim i tehnologicheskim parametram. Izdanie ofocialnoe. - M.: Standart-inform. - 2014. - 19s.

11. Danilov, O. S., Miheev, V. A., \& Moskalenko, T. V. (2011). Vzaimosvyaz geneticheskih i tehnologicheskih parametrov uglej, prinyatyh v klassifikacii, so strukturnymi parametrami ih organicheskoj massy. Gornyj informacionno-analiticheskij byulleten (nauchno-tehnicheskij zhurnal), (8).

12. Zheldakov, M. E., \& Ivanova, Ė. I. (1980). Spravochnik po kachestvu antracitov Sovetskogo Soyuza. Nedra, 99.

13. Vyalov, V. (1994). Kachestva i svojstva antracitov osnovnyh ugolnyh bassejnov i mestorozhdenij SNG i ih racionalnoe ispolzovanie. Obzornaya informaciya. Geologiya, metody poiskov, razvedki i ocenki mestorozhdenij toplivno-energeticheskogo syrya, (6), 1-74.

14. Karkashadze, G. G., Alekseev, A. D., Starikov, G. P., Vasilkovskij, V. A., \& Spozhakin, A. (2009). Sovershenstvovanie metodiki rascheta nagruzki na ochistnoj zaboj s uchetom davleniya metana $\mathrm{v}$ ugolnom plaste. Gornyj zhurnal, (4), 47-50.

15. Ivanov, V. P. (2015). Promyshlenno-energeticheskaya klassifikaciya dlya ocenki racionalnogo ispolzovaniya uglej. Izvestiya Tomskogo politehnicheskogo universiteta. Inzhiniring georesursov, 326(7). 